\title{
Antibacterial Spectrum and some other Characteristics of an Antimicrobial Factor produced by Yersinia Ruckeri
}

\author{
By Ungvild Wasteson, Anne-Berit Hvaal, Henning Sørum, Egil Myhr and Kåre Fossum \\ Department of Microbiology and Immunology, Norwegian College of Veterinary Medicine, Oslo, \\ and Department of Fish Diseases, National Veterinary Institute, Oslo, Norway.
}

\begin{abstract}
Wasteson, Y., A.-B. Hvaal, H. Sørum, E. Myhr and K. Fossum: Antibacterial spectrum and some other characteristics of an antimicrobial factor produced by Yersinia ruckeri. Acta vet. scand. 1989, 30, 253-257. - Yersinia ruckeri produces an antibacterial factor which inhibits the growth of a wide spectrum of Gramnegative and Gram-positive bacteria, though not other strains of Y. ruckeri. The antibacterial factor was produced at low temperatures $\left(4-20^{\circ} \mathrm{C}\right)$, but not at $37^{\circ} \mathrm{C}$. The activity was lost after treatment of the supernatant with chloroform, UV-light and after boiling of the supernatant. One did not succeed in obtaining the antibacterial factor in a sterile solution.
\end{abstract}

\section{Introduction}

Early in the 1980-es infections caused by Yersinia ruckeri (yersiniosis or Redmouth disease) spread rapidly in European salmonid hatcheries. According to Michel \& Faivre (1987) the concomitant occurrence of other bacterial diseases, such as furunculosis and vibriosis, showed a diminishing trend.

Michel \& Faivre (1987) reported that Y. ruckeri produced an antimicrobial factor which inhibited growth of fish pathogens such as Vibrio anguillarum and Aeromonas spp. They suggested that this antimicrobial factor might explain the apparent change in disease pattern, although this theory was not supported by experimental work.

Searching for the ability of various aquatic bacteria, including fish pathogens, to produce bacteriocins, we found that Y.ruckeri produced a factor which inhibited the growth of several other bacterial species, but not strains of $Y$. ruckeri itself.
The present paper reports on the antibacterial spectrum and some of the other characteristics of the Y.ruckeri antimicrobial factor.

Materials and methods

Bacterial strains

All the Y. ruckeri-strains used in this work were isolated from diseased fish at the National Veterinary Institute, Oslo, Norway. Six strains (NVH 3754 to NVH 3759) representing all the 3 serovars isolated in Norway, were used in most of the experiments, though 35 other strains have been tested with regard to the production of the antimicrobial factor.

The fish pathogens Hafnia sp., Citrobacter sp., Enterobacter sp., were isolated at the National Veterinary Institute from fish with clinical symptoms of disease. The other organisms included were from our own culture collection (NVH). 


\section{Demonstration of antimicrobial activity}

The method described by Fredericq (1957) for the demonstration of production of colicins was slightly modified, and used to demonstrate the growth-inhibiting effect on other bacteria.

$Y$. ruckeri-strains were inoculated on agar plates (Blood agar base nr. 2, Difco), and incubated at different temperatures $\left(4^{\circ} \mathrm{C}\right.$, $15^{\circ} \mathrm{C}, 20^{\circ} \mathrm{C}$ and $37^{\circ} \mathrm{C}$, though mostly at $15^{\circ} \mathrm{C}$ ) for $48 \mathrm{~h}$. The bacteria were then killed by treating the plates with chloroform vapour, the bacterial colonies were removed, and the plates again treated with chloroform vapour. A filter paper moistened with a culture broth $\left(>10^{7}\right.$ bacteria $\left./ \mathrm{ml}\right)$ of different test bacteria was placed on the agar plates for 5-10 min, and then removed. After incubation for 1-2 days, inhibition zones of various size could be observed where the colonies of Y. ruckeri had been (Fig. 1).

Strains of $Y$.ruckeri were also grown in nutrient broth (meat extract broth), centrifuged (3000 rpm for $20 \mathrm{~min}$ ), and $0.1 \mathrm{ml}$ of the supernatant applied in wells in the agar, the surface of which had been inoculated in advance with the test organisms. Zones of inhibition occurred as shown in Fig. 2.

\section{Isolation and characterization of the antimicrobial factor}

Several different methods were used in attempts to isolate the Y.ruckeri factor from the bacteria.

$Y$. ruckeri was grown in nutrient broth, centrifuged, and the supernatant filtrated through millipore-filters (Millipore Corporation, Bedford, USA) with pores of $0.45 \mu \mathrm{m}$ or $0.22 \mu \mathrm{m}$. The filters were also saturated with nutrient broth before filtration of the $Y$. ruckeri culture to try to prevent passive absorption of the factor.

The supernatant was treated with UV-radiation (intensity $640 \mathrm{uw} / \mathrm{cm}^{2}, 245 \mathrm{~nm}$ ) for $3 \mathrm{~h}$, and then tested for antimicrobial activity. The heat stability of the antimicrobial factor was tested by boiling the supernatant $\left(100^{\circ} \mathrm{C}\right.$

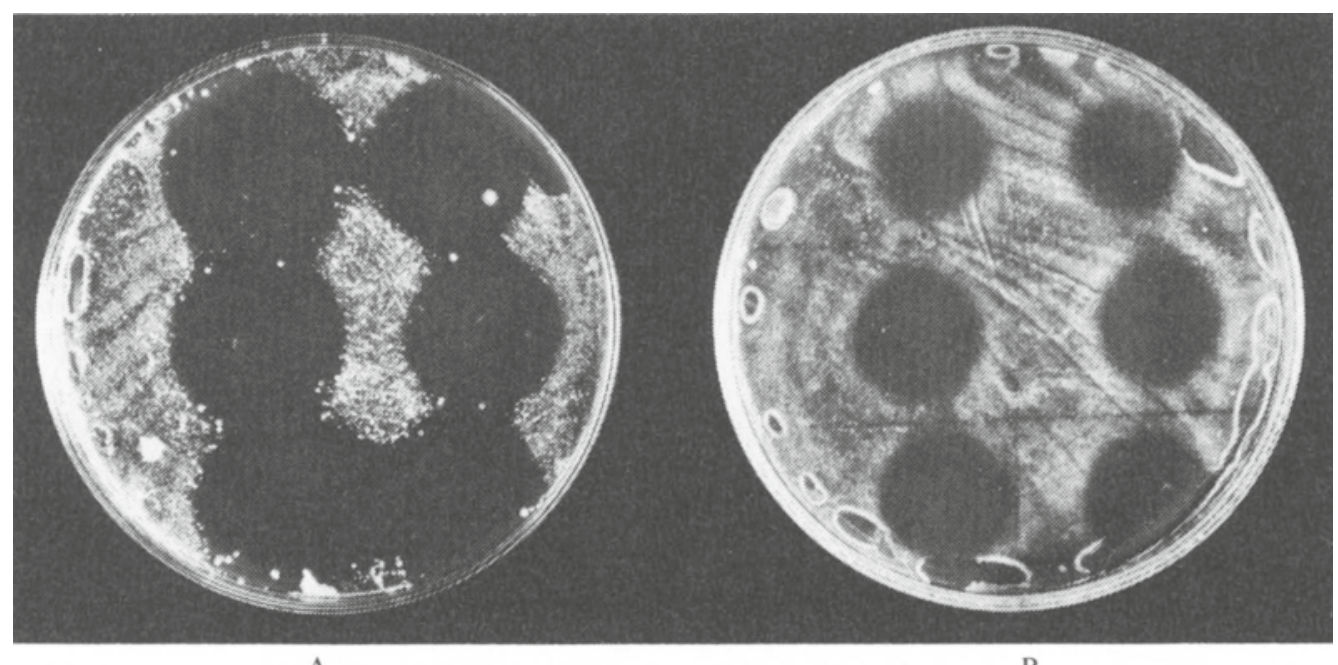

A

B

Figure 1. Effect of the antimicrobial factor produced by six different strains of Yersinia ruckeri, demonstrated on cultures of Micrococcus luteus (A) and a strain of Escherichia coli (B). 


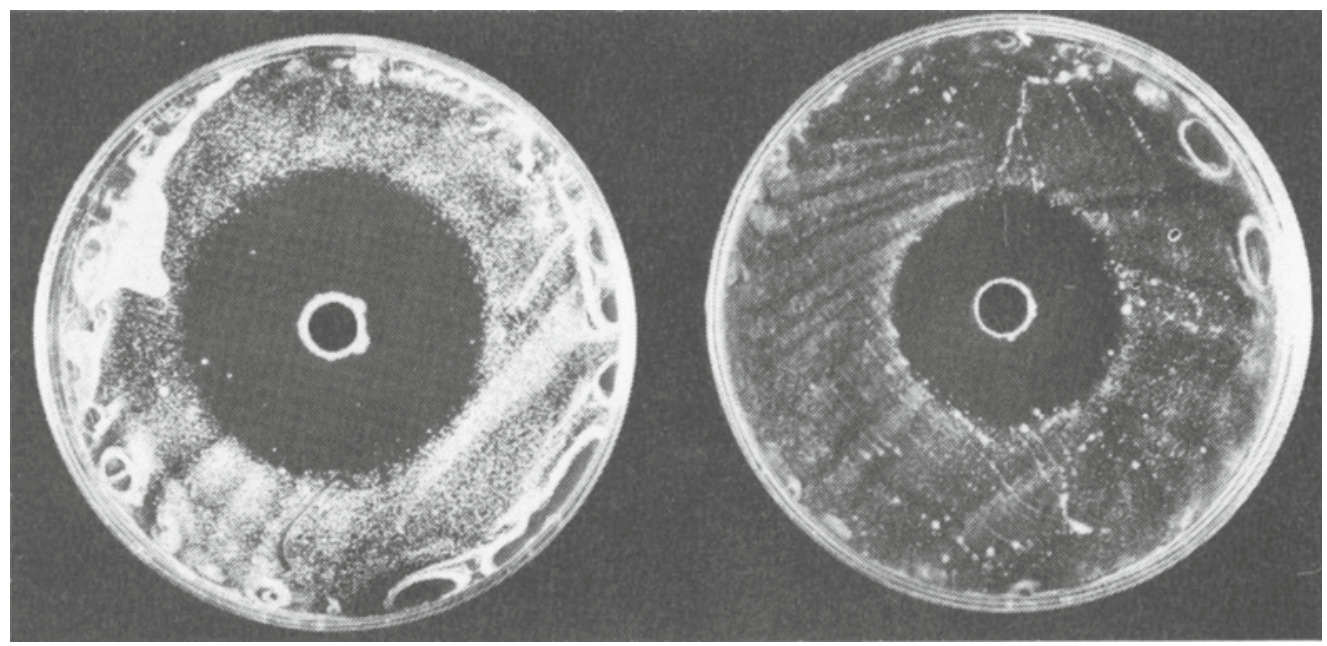

A

B

Figure 2. Antimicrobial activity in broth culture of Yersinia ruckeri, NVH 3759, demonstrated on cultures of Micrococcus luteus (A) and a strain of Escherichia coli (B).

for $5 \mathrm{~min}$ ) before testing for antimicrobial activity.

Chloroform was added to the supernatant to a concentration of $1.5 \%$, and the suspension, after thorough mixing, was centrifuged once more. This second supernatant was tested for antimicrobial activity. Y. ruckeristrains were also grown in nutrient broth in a dialyzer tube (Spectrapor, Spectrum Medical Industries, Los Angeles, USA) placed in nutrient broth, to see if the antimicrobial factor would pass through the dialyzer membrane.

\section{Results and discussion}

All the strains of Y.ruckeri tested showed antimicrobial activity. Tables 1 and 2 show the inhibitory spectrum of the Y.ruckerifactor of the 6 more extensively investigated strains on some fish pathogenic organisms and some Gram-negative animal pathogens. The growth of the Y.ruckeri-strains was not inhibited by the factor, a finding that is not consistent with the factor being an ordinary bacteriocin, or ruckericin. However, $Y$. ruckeri did inhibit growth of the closely related bacteria $Y$.enterocolitica and $Y$. pseudotuberculosis.

The growth of the strains of $V$. parahaemolyticus, V. salmonicida and a Vibrio sp. $(42-204 / 83)$ was not inhibited. On the other hand, the growth of all strains of Aeromonas salmonicida, Aeromonas hydrophila and $V$. anguillarum was inhibited by all the 6 strains of Y.ruckeri. This is consistent with the results of Michel \& Faivre. The growth of several animal pathogenic Gram-negatives was also inhibited. The antibacterial spectrum of the Y. ruckeri strains did, however, vary a little.

The growth of Moraxella sp., Brucella abortus, Bordetella bronchiseptica and Pseudomonas aeruginosa was not inhibited.

Among the Gram-positive organisms, the growth of Micrococcus luteus, a bacterium used in biological assays for antibiotics, was 
Table 1. Effect of the antimicrobial factor of Yersinia ruckeri on some fish pathogenic bacteria.

\begin{tabular}{|c|c|c|c|c|c|c|}
\hline \multirow[b]{2}{*}{$\underline{\text { Strains }}$} & \multicolumn{6}{|c|}{ Strains of Yersinia ruckeri } \\
\hline & $\begin{array}{r}\text { NVN } \\
3754\end{array}$ & $\begin{array}{r}\text { NVH } \\
3755\end{array}$ & $\begin{array}{r}\text { NVH } \\
3756\end{array}$ & $\begin{array}{l}\text { NVH } \\
3757\end{array}$ & $\begin{array}{r}\text { NVH } \\
3758\end{array}$ & $\begin{array}{r}\text { NVH } \\
3759\end{array}$ \\
\hline $\begin{array}{l}\text { Yersinia ruckeri } \\
\text { (all } 6 \text { strains) }\end{array}$ & - & - & - & - & - & - \\
\hline Aeromonas salmonicida & $H$ & $H$ & + & + & + & $H$ \\
\hline Aeromonas hydrophila & + & $H$ & + & + & + & + \\
\hline Vibrio parahaemolyticus & - & - & - & - & - & - \\
\hline $\begin{array}{l}\text { Vibrio anguillarum } \\
\text { (Lab. strain) }\end{array}$ & + & + & + & + & + & + \\
\hline $\begin{array}{l}\text { Vibrio anguillarum } \\
\text { FT } 18010\end{array}$ & + & $H$ & $H$ & $H$ & $H$ & $H$ \\
\hline $\begin{array}{l}\text { Vibrio salmonicida } \\
\text { (4 different strains) }\end{array}$ & - & - & - & - & - & - \\
\hline Vibrio sp. A703/82 & ++ & $H$ & H & $H$ & $H$ & H+ \\
\hline Vibrio sp. $42-204 / 83$ & - & - & - & - & - & - \\
\hline Enterobacter sp. & + & + & + & + & + & + \\
\hline Hafnia sp. & + & $H$ & $H$ & + & + & + \\
\hline Citrobacter sp. & + & + & + & + & + & + \\
\hline
\end{tabular}

- No inhibiting effect on growth

+ Inhibiting zone diameter 0-20 mm

+ Inhibiting zone diameter $20-40 \mathrm{~mm}$

H+ Inhibiting zone diameter greater than $40 \mathrm{~mm}$

Table 2. Effect of the antimicrobial factor of Yersinia ruckeri on some Gram-negative animal pathogenic bacteria.

\begin{tabular}{|c|c|c|c|c|c|c|}
\hline \multirow{3}{*}{ Strains } & \multicolumn{6}{|c|}{ Strains of Yersinia ruckeri } \\
\hline & NVH & NVH & NVH & NVH & NVH & $\begin{array}{r}\text { NVH } \\
3759\end{array}$ \\
\hline & & & 3756 & 3757 & & \\
\hline E. coli 2770 & + & + & $H$ & + & + & H \\
\hline Enteropathogenic $E$. coli & + & + & H & + & + & + \\
\hline Klebsiella sp. & + & + & + & + & + & + \\
\hline Proteus sp. & + & + & $H$ & + & + & $H$ \\
\hline Salmonella typhimurium & + & + & + & + & - & + \\
\hline Salmonella dublin & + & + & $H$ & H & + & + \\
\hline Edwardsiella tarda & + & + & $H$ & + & + & $H$ \\
\hline Moraxella sp. & - & - & - & - & - & - \\
\hline Brucella abortus & - & - & - & - & - & - \\
\hline Bordetella bronchiseptica & - & - & - & - & - & - \\
\hline Pseudomonas aeruginosa & - & - & - & - & - & - \\
\hline Pasteurella multocida & $H$ & + & H & H & + & + \\
\hline Yersinia enterocolitica & $H$ & $H$ & H & $H$ & $H$ & $H$ \\
\hline Yersinia pseudotuberculosis & $H$ & H & H & + & H & H \\
\hline
\end{tabular}


strongly inhibited. The growth of Streptococcus faecalis and Bacillus cereus was also inhibited, while the growth of Micrococcus sp., Staphylococcus aureus, Erysipelothrix rhusiopathiae, Rhodococcus equi and Bacillus subtilis was not.

The antibacterial factor was produced at low temperatures $\left(4-20^{\circ} \mathrm{C}\right)$. When $Y$. ruckeri was cultured at $37^{\circ} \mathrm{C}$, no antibacterial activity could be demonstrated. The activity was stable for at least 1 month in broth culture, when stored at $15^{\circ} \mathrm{C}$.

We have not yet succeeded in isolating the antimicrobial factor from the bacterial cell suspension. The inhibiting activity seems to be lost both after UV-radiation and chloroform treatment of the supernatant. The antimicrobial activity disappeared after boiling of the supernatant.

Nor could any antibacterial activity be demonstrated in the nutrient broth outside the dialyzer membrane, only in that from the inside of the membrane.

After filtration of supernatant through millipore-filters, antimicrobial activity could not be demonstrated. According to Senior et al. (1970), filtration of colicin suspensions may result in colicins being absorbed to filters.

\section{References}

Fredericq P: Colicins. Ann. Rev. Microbiol. 1957, $11,7-22$.

Michel C, Faivre B: In vitro and in vivo study of an antimicrobial activity displayed by the Redmouth disease agent, Yersinia ruckert. Ann. Rech. Vet. 1987, 18, 43-46.

Senior, BW, Richardson H, Emslie-Smith AH: Sterilisation of colicin preparations. J. Microbiol. 1970, 3, 585-592.

\begin{abstract}
Sammendrag
Antibakterielt spektrum og enkelte karakteristiske egenskaper for en antibakteriell faktor produsert av Yersinia ruckeri.

Det ble funnet at Yersinia ruckeri produserer en antibakteriell faktor som hemmer veksten av et vidt spektrum av Gram-negative og Gram-positive bakterier, men den hemmer ikke veksten av andre stammer av $Y$. ruckeri. Faktoren dannes ved lave temperaturer $\left(4^{\circ} \mathrm{C}-20^{\circ} \mathrm{C}\right)$, men ikke ved $37^{\circ} \mathrm{C}$. Aktiviteten ble borte etter behandling av supernatanten med kloroform, UV-lys og etter koking av supernatanten. En lyktes ikke i å få separert den antibakterielle faktoren fra bakteriesuspensjoner.
\end{abstract}

(Received April 26, 1988; accepted August 26,1988).

Reprints may be requested from: Yngvild Wasteson, Department of Microbiology and Immunology, Norwegian College of Veterinary Medicine, P. O. Box 8146 Dep., 0033 Oslo 1, Norway. 
